\title{
Thyroid Hormone-Carbohydrate Interaction in the Rat
}

\author{
CORRELATION BETWEEN AGE-RELATED REDUCTIONS IN THE \\ INDUCIBILITY OF HEPATIC MALIC ENZYME BY TRIIODO-L-THYRONINE
}

AND A HIGH CARBOHYDRATE, FAT-FREE DIET

\author{
Mary Ann Forciea, Harold L. Schwartz, Howard C. Towle, Cary N. Mariash, \\ F. E. KAISER, and J. H. OPPENHEIMER, Division of Endocrinology and \\ Metabolism, Department of Medicine, Department of Biochemistry, University \\ of Minnesota, Minneapolis, Minnesota 55455
}

A B S T RACT Previous studies from this laboratory have demonstrated an age-related decrease in hepatic malic enzyme (ME) levels and in the response of $\mathrm{ME}$ to triiodo-L-thyronine $\left(\mathrm{T}_{3}\right)$. Moreover, we have recently shown a synergistic interaction of $\mathrm{T}_{3}$ and a high carbohydrate diet in the induction of this enzyme. Studies were therefore undertaken to assess the response of aging rats to a high carbohydrate diet and to test the effect of such dietary manipulations on the responsiveness of $\mathrm{ME}$ to $\mathrm{T}_{3}$. For this purpose, a new radioimmunoassay for ME was developed that, because of a 10-fold higher sensitivity, was particularly suited to the measurement of the low concentrations of hepatic enzyme in older animals. The level of ME per milligram of DNA fell $\sim 70 \%$ between 1 and 6 mo with only minor further changes demonstrated between 6 and 18 mo. In contrast, the level of $\mathrm{ME}$ per milligram DNA in brain was slightly increased in the older animals. Although the absolute increment of hepatic $\mathrm{ME}$ resulting from seven daily injections of $\mathrm{T}_{3}(15 \mu \mathrm{g} / 100 \mathrm{~g}$ body wt) fell with age, the ratio of the $\mathrm{ME}$ content per milligram DNA to that observed in control animals maintained on a regular chow diet remained relatively constant with an average value of 11.1. The responsivity of hepatic ME to a high carbohydrate, fat-free diet also decreased with age and could not be attributed exclusively to a reduction in food consumption. The agerelated reduction in $\mathrm{ME}$ responsivity to dietary stimuli appeared to be due to a reduction in the formation of the specific messenger, (m)RNA for ME as determined in an in vitro translational assay. Our data are consistent with the following hypothesis. There is an age-related

Address reprint requests to Dr. J. H. Oppenheimer.

Received for publication 7 November 1980 and in revised form 30 January 1981. decreased hepatic responsivity to a high carbohydrate dietary stimulus. Thyroid hormone administration, as previously postulated by us, interacts with a product or an intermediate of carbohydrate metabolism in a multiplicative fashion. As a consequence, the absolute increment of $\mathrm{ME}$ induced by $\mathrm{T}_{3}$ administration also declines with age.

\section{INTRODUCTION}

In a previous study we have shown that in rat liver there appears to be a progressive age-related decrease in the level of two triiodo-L-thyronine $\left(\mathrm{T}_{3}\right)^{1}$ responsive enzymes, cytosolic malic enzyme (ME), and mitochondrial $\alpha$-glycerophosphate dehydrogenase, as well as a decrease in the response of the enzymes to a single injection of triiodothyronine $\left(\mathrm{T}_{3}\right)(1)$. Since differences in basal enzyme levels and their response to $T_{3}$ could not be attributed to alterations in nuclear $T_{3}$ occupancy, we concluded that these age-related changes reflected postreceptor modifications of the $\mathrm{T}_{3}$ nuclear signal. In more recent studies from our laboratory we have also shown what appears to be a synergistic interaction between thyroid hormone and a factor associated with a high carbohydrate, fat-free diet in the induction of $\mathrm{ME}$ and other lipogenic enzymes (2). The concept was advanced that the stimulus for the generation of the specific messenger $(\mathrm{m}) \mathrm{RNA}$ coding for ME represented the product of the signal derived from the $\mathrm{T}_{3}$ nuclear interaction and that derived from the carbohydrateinduced stimulus. As a corollary of this formulation, it appeared at least theoretically possible that the diminished response of $\mathrm{ME}$ to $\mathrm{T}_{3}$ in the aging rat was related to a primary reduction in the carbohydrate-

\footnotetext{
${ }^{1}$ Abbreviations used in this paper: ME, malic enzyme;
} RIA, radioimmunoassay; $\mathrm{T}_{3}$, triiodothyronine. 
generated signal. Accordingly, we undertook a series of experiments to assess the response of the aging animals to a high carbohydrate diet and the influence of concomitant $T_{3}$ administration on such dietary manipulation. We specifically examined the relationship between daily food intake and the intrinsic hepatic responsivity to the induction stimulus. In order to increase the sensitivity of our measurements in the aging rat and to be certain that we were determining enzyme mass rather than activity we developed a new radioimmunoassay for this enzyme. Our findings further emphasize the important influence of carbohydrate metabolism on the expression of thyroid hormone effects at a postreceptor level. The results document an age-related diminution in hepatic lipogenic enzyme response to dietary carbohydrate administration, which may be central to the decreased responsivity to $T_{3}$.

\section{METHODS}

Male Sprague-Dawley rats from 1 to $18 \mathrm{mo}$ of age were purchased from Taconic Farms, Germantown, N. Y. Control rats were maintained on Purina Lab Chow (Ralston Purina Co., St. Louis, Mo.). : Groups of rats were treated with daily intraperitoneal injections of $15 \mu \mathrm{g}$ of $\mathrm{T}_{3}$ (Sigma Chemical Co., St. Louis, Mo.) per $100 \mathrm{~g}$ body wt for $7 \mathrm{~d}$. Dietary induction of ME was carried out by feeding rats a high carbohydrate diet (fat free test diet, ICN Nutritional Biochemicals, Cleveland, Ohio) for $4 \mathrm{~d}$. This diet differs from the normal lab chow mainly in the absence of fat and in the presence of all carbohydrate in the form of a simple sugar, sucrose $(60 \%$ by weight) (3).

The methods utilized for preparation of purified rat hepatic $\mathrm{ME}$ and rabbit anti-ME anti-serum have been previously described (4). Rat hepatic and brain cytosol was prepared by centrifugation of $10 \%$ tissue homogenate in $0.32 \mathrm{M}$ sucrose $-3 \mathrm{mM} \mathrm{MgCl}_{2}$ at $158,000 \mathrm{~g}$ for $60 \mathrm{~min}$ in a Beckman TY65 rotor (Beckman Instruments, Inc., Fullerton, Calif.). Purified $\mathrm{ME}$ was iodinated by the method of Bolton and Hunter (5). Standard curves, ranging from 5 to $250 \mathrm{ng}$ were routinely included in all assays. All samples were diluted in phosphosaline buffer $(0.01 \mathrm{M}$ sodium phosphate $-0.15 \mathrm{M}$ sodium chloride $-0.1 \%$ sodium azide) containing $1 \%$ bovine serum albumin. Sample volume used for standards or cytosol, was $400 \mu \mathrm{l}$ to which were added $100 \mu \mathrm{l}$ of the anti-ME antiserum (diluted 1/5,000 in phosphosaline buffer containing 3\% normal rabbit serum), and $100 \mu \mathrm{l}$ of phosphosaline buffer $-1 \%$ bovine serum albumin containing $\sim 10,000 \mathrm{cpm}$ of ${ }^{125} \mathrm{I}-$ labeled ME. This mixture was incubated for $24 \mathrm{~h}$ at $4^{\circ} \mathrm{C}$. At the end of this period $100 \mu$ l of a 1:1 dilution of goat antirabbit serum antiserum (Antibodies, Inc., Davis, Calif.) in phosphosaline buffer - $1 \%$ bovine serum albumin were added and the mixture incubated for a further $24 \mathrm{~h}$. At that time samples were centrifuged and decanted. The resulting pellets were counted in a Packard Autogamma (Packard Instruments, Inc., Downers Grove, Ill.). Calculations were performed by use of a computer program kindly supplied by Dr. David Rodbard (National Institutes of Health) for best fit of log-dose response data (6).

$\mathrm{ME}$ activity was measured by the method of $\mathrm{Hsu}$ and Lardy (7). $1 \mathrm{U}$ of activity was defined as that amount of enzyme required to reduce $1 \mathrm{nmol}$ of $\mathrm{NADP}^{+}$in $1 \mathrm{~min}$. Specific activity of the purified ME was 39,600 U/mg.

Quantitation of the binding capacity of the specific $T_{3}$ - nuclear receptors in rat liver was carried out as previously described (8). Nuclear content of specifically bound $T_{3}$ was calculated from the product of the nuclear/plasma $\left[{ }^{125} \mathrm{I}\right] \mathrm{T}_{3}$ ratio and the plasma concentration of $T_{3}(9)$. Plasma $T_{3}$ concentration was measured by the immunoassay method of Surks et al. (10). The activity levels of the mRNA for ME were quantitated using a previously described in vivo translational assay in an endonuclease-treated reticulocyte lysate system (4).

Average daily food intake was measured during a period of $4 \mathrm{~d}$. Younger animals were housed four per cage. Older rats ( 6 to $27 \mathrm{mo}$ ) were grouped two per cage. Measurements were made for at least four groups at each age.

For the determination of the rate of plasma disappearance of $\mathrm{T}_{3}$, rats at $2 \mathrm{mo}$ and $2 \mathrm{y}$ of age were injected intravenously with a tracer dose $\left(5 \mathrm{ng} / 100 \mathrm{~g}\right.$ body wt) of $\left.{ }^{[25} \mathrm{I}\right] \mathrm{T}_{3}$. Serial blood samples were taken from the cut tail. Aliquots of plasma were treated with TCA to remove accumulating $\left[{ }^{125} I\right]-$ iodide (11).

DNA was measured as described by Giles and Myers (12) and RNA according to Munro and Fleck (13). Protein was measured by the method of Lowry et al. (14).

\section{RESULTS}

Radioimmunoassay for ME. A representative standard displacement curve obtained by the logit-log transformation of values and a best fit computer generated curve is illustrated in Fig. 1. The intraassay coefficient of variation was $10 \%$ whereas interassay coefficient of variation averaged $15.5 \%$. Fig. 1 also illustrates that the shape of the standard displacement curve produced by serial dilution of brain cytosol is indistinguishable from that obtained with hepatic cytosol, thus justifying the use of the antiserum in the

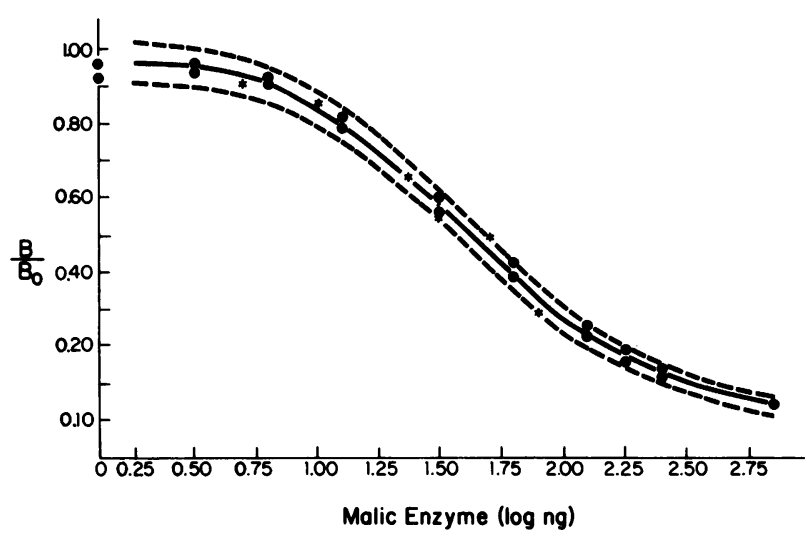

FIGURE 1 RIA of ME. 0 , represent duplicate samples of increasing concentrations of purified rat hepatic ME prepared as previously described (4). A best-fit curve was computed using the logit-log linearization program of Dr. D. Rodbard (National Institutes of Health), Bethesda, Md. (7). The data are then plotted in conventional fashion. - - , 95\% confidence limits of the curve. Serial dilutions of rat brain cytosol $\left({ }^{*}\right)$ were simultaneously assayed as described in Methods. The parallelism of these points to those of the standard curve indicates identity of the immunologic determinants of $\mathrm{ME}$ from liver and brain: $\mathrm{B} / \mathrm{B}_{\mathbf{0}}=$ ratio of total counts per minute bound at any concentration to the cpm bound at the lowest concentration used. 


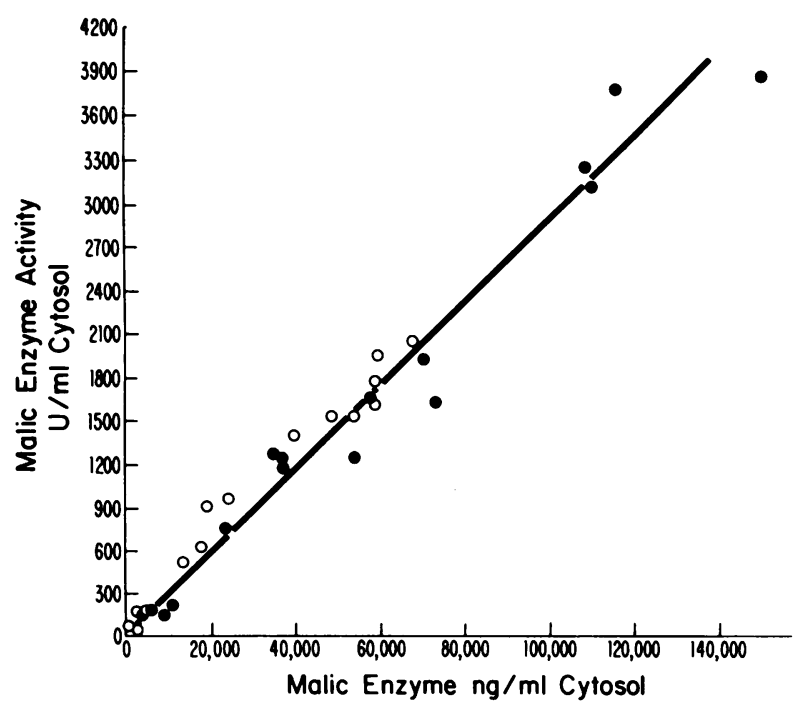

FigURE 2 Comparison of the mass of hepatic ME measured by RIA with the ME activity measured by conventional spectrophotometric assay (8). Hepatic cytosol from animals on regular diet, high carbohydrate diet, and under treatment with $\mathrm{T}_{3}$ was analyzed. $\bullet, 1$ mo rat; $\bigcirc, 6$ mo rat.

quantitation of brain ME. The correspondence between concentrations of ME mass measured by radioimmunoassay (RIA) and ME activity determinations performed by a standard spectrophotometric assay is illustrated in Fig. 2. The large range in ME concentrations was obtained by the intraperitoneal injection of $\mathrm{T}_{3}(200 \mu \mathrm{g} / 100 \mathrm{~g}$ body wt) into 1 - and 6-mo-old animals for a variable number of days. The correlation coefficient between the standard spectrophotometric assay and the RIA was 0.98 , confirming earlier inferences that the changes in ME activity reflected changes in enzyme mass (1). We estimated from the specific activity of purified preparations that the limit of resolution of the spectrophotometric method was 235 $\mathrm{ng} / \mathrm{ml}$ cytosol, whereas the limit for the RIA is only $25 \mathrm{ng} / \mathrm{ml}$ cytosol. The enhanced sensitivity was especially helpful in our studies of the ME activity in older rats since the basal concentration of this enzyme in such animals was exceedingly low.

Nuclear binding parameters as a function of age. Table I lists nuclear $\mathrm{T}_{3}$ binding parameters as well as some general biochemical characteristics of liver in relationship to age. In confirmation of our previous report, the concentration of plasma $T_{3}$ was higher in animals at $1 \mathrm{mo}$ of age $(0.67 \pm 0.04 \mathrm{ng} / \mathrm{ml})$ than in the older groups in which it ranged from $0.38 \pm 0.05$ to $0.48 \pm 0.07$ $\mathrm{ng} / \mathrm{ml}$. The nuclear $\mathrm{T}_{3}$ content determined from the product of the isotopic nuclear/plasma $\left[{ }^{125} \mathrm{I}\right] \mathrm{T}_{3}$ ratio and the plasma $T_{3}$ RIA, remained remarkably constant

TABLE I

Hepatic Parameters in the Euthyroid Rat as a Function of Age

\begin{tabular}{|c|c|c|c|c|}
\hline & \multicolumn{4}{|c|}{ Age } \\
\hline & \multicolumn{4}{|c|}{ mo } \\
\hline & 1.5 & 6 & 12 & 18 \\
\hline Body wt, $g$ & $143 \pm 29$ & $435 \pm 71$ & $615 \pm 46$ & $586 \pm 44$ \\
\hline Plasma $\mathrm{T}_{3}, n g / m l$ & $0.67 \pm 0.04$ & $0.38 \pm 0.05$ & $0.48 \pm 0.07$ & $0.44 \pm 0.09$ \\
\hline$\frac{\mathrm{N} / \mathrm{P}}{\mathrm{mg} \mathrm{DNA}}$ & $0.389 \pm 0.117$ & $0.530 \pm 0.180$ & $0.533 \pm 0.083$ & $0.516 \pm 0.089$ \\
\hline Nuclear $\mathrm{T}_{3}, n g / m g D N A$ & $0.26 \pm 0.08$ & $0.20 \pm 0.07$ & $0.26 \pm 0.04$ & $0.23 \pm 0.05$ \\
\hline Receptor $\mathrm{B}_{\max }, n g T_{3} / m g D N A$ & $0.39 \pm 0.10$ & $0.49 \pm 0.19$ & $0.57 \pm 0.17$ & $0.45 \pm 0.07$ \\
\hline$k_{\mathrm{a}} \times 1 \mathrm{nM}$ & $0.87 \pm 0.18$ & $0.90 \pm 0.15$ & $1.10 \pm 0.13$ & $1.05 \pm 0.21$ \\
\hline Liver wt, $g$ & $5.8 \pm 1.1$ & $13.7 \pm 2.3$ & $16.4 \pm 0.9$ & $16.6 \pm 1.7$ \\
\hline$\frac{\text { Liver }}{\text { Body }} \times 100$ & $4.0 \pm 0.3$ & $3.2 \pm 0.2$ & $2.7 \pm 0.2$ & $2.8 \pm 0.4$ \\
\hline DNA, $m g / g$ liver & $3.39 \pm 0.52$ & $2.93 \pm 0.38$ & $2.94 \pm 0.31$ & $3.28 \pm 0.25$ \\
\hline RNA/DNA & $1.68 \pm 0.4$ & $1.72 \pm 0.42$ & $1.46 \pm 0.66$ & $1.39 \pm 0.58$ \\
\hline Cytosol protein, $\mathrm{mg} / \mathrm{g}$ liver & $85.0 \pm 7.8$ & $86.4 \pm 10.0$ & $91.4 \pm 3.9$ & $91.8 \pm 4.0$ \\
\hline$n$ & 4 & 8 & 8 & 8 \\
\hline
\end{tabular}

All measurements were carried out as described in Methods. Values represent the mean and SD for the number $(n)$ of animals indicated. (N/P)/mg DNA = nuclear:plasma ${ }^{125} I_{-} T_{3}$ concentration ratio; $B_{\max }$, maximal binding capacity. 
TABLE II

Effect of Age, Diet, and Treatment on ME Content

\begin{tabular}{|c|c|c|c|c|c|c|c|c|c|c|c|}
\hline \multirow[b]{3}{*}{ Age } & \multicolumn{6}{|c|}{ Chow diet } & \multicolumn{4}{|c|}{ High carbohydrate diet } & \multirow[b]{3}{*}{$\mathbf{R}$} \\
\hline & \multirow[b]{2}{*}{ Status } & \multicolumn{2}{|c|}{ Weight } & \multirow{2}{*}{$\frac{\mathrm{ME}}{\mathrm{U} / \mathrm{mg} \text { DNA }}$} & \multirow[b]{2}{*}{$\Delta \mathbf{M E}$} & \multirow[b]{2}{*}{$\mathbf{R}$} & \multicolumn{2}{|c|}{ Body wt. } & \multirow{2}{*}{$\frac{M E}{U / m g ~ D N A}$} & \multirow[b]{2}{*}{$\Delta \mathrm{ME}$} & \\
\hline & & Begin & Final & & & & Begin & Final & & & \\
\hline mo & & & & & & & & & & & \\
\hline 1.0 & Basal & $\begin{array}{r}74 \\
\pm 8\end{array}$ & $\begin{array}{l}115 \\
\pm 17\end{array}$ & $\begin{array}{r}669 \\
\pm 183\end{array}$ & & & $\begin{array}{l}71 \\
\pm 6\end{array}$ & $\begin{array}{r}108 \\
\pm 7\end{array}$ & $\begin{array}{r}6,232 \\
\pm 1,343\end{array}$ & & \\
\hline & $+\mathrm{T}_{3}$ & $\begin{array}{r}71 \\
\pm 7\end{array}$ & $\begin{array}{r}107 \\
\pm 8\end{array}$ & $\begin{array}{r}6,284 \\
\pm 1,583\end{array}$ & $\begin{array}{r}5,615 \\
\pm 1,583\end{array}$ & 9.4 & $\begin{array}{r}70 \\
\pm 6\end{array}$ & $\begin{array}{r}101 \\
\pm 12\end{array}$ & $\begin{array}{l}9,051 \\
\pm 687\end{array}$ & $\begin{array}{l}2,819 \\
\pm 687\end{array}$ & 1.5 \\
\hline 1.5 & Basal & $\begin{array}{r}113 \\
\pm 5\end{array}$ & $\begin{array}{r}115 \\
\pm 10\end{array}$ & $\begin{array}{r}482 \\
\pm 42\end{array}$ & & & $\begin{array}{r}100 \\
\pm 8\end{array}$ & $\begin{array}{r}136 \\
\pm 15\end{array}$ & $\begin{array}{l}4,432 \\
\pm 909\end{array}$ & & \\
\hline & $+\mathrm{T}_{3}$ & $\begin{array}{r}103 \\
\pm 15\end{array}$ & $\begin{array}{r}139 \\
\pm 19\end{array}$ & $\begin{array}{r}3,866 \\
\pm 1,048\end{array}$ & $\begin{array}{r}3,383 \\
\pm 1,048\end{array}$ & 8.0 & $\begin{array}{r}106 \\
\pm 9\end{array}$ & $\begin{array}{r}125 \\
\pm 11\end{array}$ & $\begin{array}{r}7,059 \\
\pm 1,391\end{array}$ & $\begin{array}{r}2,627 \\
\pm 1,391\end{array}$ & 1.6 \\
\hline 6.0 & Basal & $\begin{array}{r}439 \\
\pm 54\end{array}$ & $\begin{array}{r}448 \\
\pm 53\end{array}$ & $\begin{array}{r}215 \\
\pm 41\end{array}$ & & & $\begin{array}{r}418 \\
\pm 38\end{array}$ & $\begin{array}{r}425 \\
\pm 40\end{array}$ & $\begin{array}{l}2,427 \\
\pm 496\end{array}$ & & \\
\hline & $+\mathrm{T}_{3}$ & $\begin{array}{r}399 \\
\pm 22\end{array}$ & $\begin{array}{r}361 \\
\pm 21\end{array}$ & $\begin{array}{l}3,179 \\
\pm 113\end{array}$ & $\begin{array}{l}2,964 \\
\pm 113\end{array}$ & 14.8 & $\begin{array}{r}393 \\
\pm 15\end{array}$ & $\begin{array}{r}349 \\
\pm 10\end{array}$ & $\begin{array}{l}3,811 \\
\pm 511\end{array}$ & $\begin{array}{l}1,384 \\
\pm 511\end{array}$ & 1.6 \\
\hline 12.0 & Basal & $\begin{array}{r}571 \\
\pm 63\end{array}$ & $\begin{array}{r}578 \\
\pm 70\end{array}$ & $\begin{array}{r}262 \\
\pm 130\end{array}$ & & & $\begin{array}{r}614 \\
\pm 25\end{array}$ & $\begin{array}{r}595 \\
\pm 32\end{array}$ & $\begin{array}{r}782 \\
\pm 494\end{array}$ & & \\
\hline & $+\mathrm{T}_{3}$ & $\begin{array}{r}583 \\
\pm 51\end{array}$ & $\begin{array}{r}513 \\
\pm 62\end{array}$ & $\begin{array}{r}3,375 \\
\pm 1,655\end{array}$ & $\begin{array}{r}3,095 \\
\pm 1,655\end{array}$ & 12.9 & $\begin{array}{r}604 \\
\pm 26\end{array}$ & $\begin{array}{r}520 \\
\pm 20\end{array}$ & $\begin{array}{r}2,947 \\
\pm 1,169\end{array}$ & $\begin{array}{r}2,165 \\
\pm 1,169\end{array}$ & 3.8 \\
\hline 18.0 & Basal & $\begin{array}{r}608 \\
\pm 67\end{array}$ & $\begin{array}{r}610 \\
\pm 71\end{array}$ & $\begin{array}{r}251 \\
\pm 140\end{array}$ & & & $\begin{array}{r}560 \\
\pm 74\end{array}$ & $\begin{array}{r}546 \\
\pm 76\end{array}$ & $\begin{array}{l}1,053 \\
\pm 491\end{array}$ & & \\
\hline & $+\mathrm{T}_{3}$ & $\begin{array}{r}597 \\
\pm 44\end{array}$ & $\begin{array}{l}519 \\
\pm 44\end{array}$ & $\begin{array}{l}2,577 \\
\pm 905\end{array}$ & $\begin{array}{r}2,326 \\
\pm 905\end{array}$ & 10.3 & $\begin{array}{r}627 \\
\pm 27\end{array}$ & $\begin{array}{r}546 \\
\pm 64\end{array}$ & $\begin{array}{r}2,695 \\
\pm 1,009\end{array}$ & $\begin{array}{r}1,642 \\
\pm 1,010\end{array}$ & 2.6 \\
\hline
\end{tabular}

Age-related response of hepatic malic enzyme to $T_{3}$ and a high carbohydrate diet. $T_{3}(15 \mu \mathrm{g} / 100 \mathrm{~g}$ body wt) was administered by daily intraperitoneal injection for $7 \mathrm{~d}$. High carbohydrate diet was fed to the rats for $4 \mathrm{~d}$. When the diet was combined with $T_{3}$ it was given during the last 4 of the $7 \mathrm{~d}$ of hormone treatment. $R=$ ratio of $\mathrm{ME}$ in $\mathrm{T}_{3}$-treated rats to the untreated control animals. $\triangle \mathrm{ME}=\mathrm{T}_{3}$-induced increment in $\mathrm{ME}$ above basal levels.

over the age span examined. The binding capacity determined from whole nuclear assays also showed singularly little variation. The fractional occupancy of $\mathrm{T}_{3}$ ( $=$ nuclear $\mathrm{T}_{3}$ content/binding capacity) averaged $\sim 50 \%$. No significant age-dependent alterations in the nuclear $T_{3}$ affinity constant ${ }^{2}$ were observed in the

\footnotetext{
${ }^{2}$ Note that the association constant for whole nuclear $T_{3}$ binding cited in our previous studies (1) is approximately five times greater than the comparable value cited in this report (Table I). In large part, this is due to an inadvertent error in the calculation of our previous data. The results should have averaged $\sim 0.5 \mathrm{nM}$. Thus, our current results are actually approximately twice those in the earlier study, a discrepancy that is probably within the interassay variation of the method. Of particular pertinence was that in neither study was there a significant age-related change and the constancy of the in vitro assay was supported by the estimated nuclear $T_{3}$ content based on in vivo isotopic measurements.
}

whole nuclear assay. Neither were there significant changes in the DNA per gram liver, the total cellular RNA/DNA ratios, or the cytoplasmic protein content per gram liver. Liver weight as a percentage of total body weight fell significantly from 1.5 to 6 mo $(4.0$ $-2.8 \%, P<0.001)$. Total body weight continued to increase markedly over the first year of life, after which the rate of increase slowed.

$M E$ and protein levels in liver and brain as a function of age. Fig. 3 illustrates the results of measurements of the basal cytosol ME content of liver and brain in animals of different ages. In agreement with our previous report, the major fall in hepatic ME content occurred between 1 and 6 mo with only a slight decrease thereafter. In contrast, brain cytosolic ME content exhibits a modest rise with age. No consistent alteration in cytosolic protein content per milligram DNA was observed in either tissue. 


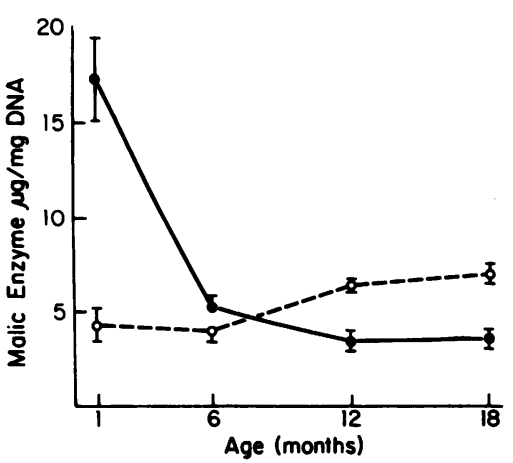

FIGURE 3 ME per milligram DNA as a function of age in liver and brain. Liver ME concentration falls, whereas brain $\mathrm{ME}$ concentration rises slightly. $\Phi$, mean $\pm S E$; $O$, liver; $O$, brain.

Effect of thyroid hormone and high carbohydrate diet on ME activity. As indicated in Table II, $7 \mathrm{~d}$ of $\mathrm{T}_{3}$ administration ( $15 \mu \mathrm{g} / 100 \mathrm{~g}$ body wt) resulted in a striking increase in the level of ME in all age groups. In confirmation of our previous report, however, the absolute increment achieved as a result of $T_{3}$ administration also diminished with age, the largest decrease occurring between 1 and 6 mo. This pattern resembled the fall in basal enzyme levels. These changes could not be attributed to age-related alterations in nuclear binding, as noted above. It also appeared unlikely that these changes were due to alterations in the metabolism of $T_{3}$ as a function of age, since the nuclear sites are nearly saturated with the level of $\mathrm{T}_{3}$ used. Nevertheless, additional experiments (Fig. 4) showed no appreciable difference in the disappearance rate of $T_{3}$ in old as compared to young rats. Of interest was the finding that the response of $\mathrm{ME}$ to the high carbohydrate, fat-free diet also diminished with

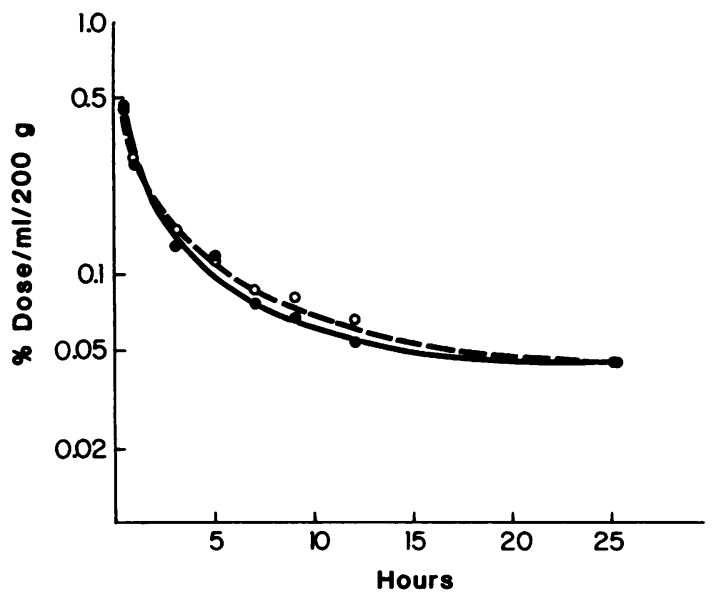

Figure 4 Plasma disappearance of $\left[{ }^{125} \mathrm{I}\right] \mathrm{T}_{3}$. Data were corrected to an ideal weight of $200 \mathrm{~g}$. Each point is the average of a group of three amimals. No significant age-related differences in the disappearance curves are apparent. $0,2 \mathrm{mo}$; $\mathrm{O}, 2 \mathrm{yr}$. age. As is apparent from Table II a similar age-related decrease in response was observed when animals were simultaneously subjected to both stimuli, daily $\mathrm{T}_{3}$ administration ( $15 \mu \mathrm{g} / 100 \mathrm{~g}$ body wt) for $7 \mathrm{~d}$ and a high carbohydrate diet during the last $4 \mathrm{~d}$. The level in ME achieved in 1-mo-old animals was in excess of that achieved with either $T_{3}$ or carbohydrate alone but not in excess of the sum of both. In the 12- and 18mo-old animals the high degree of variability in the results may have prevented the demonstration of greater effectiveness of combined stimulation.

Some insight into the mechanistic basis of these interactions can be derived from a consideration of the proportional changes in enzyme levels induced by the two stimuli rather than by the absolute increment achieved. Of interest was the finding in every age group that the administration of $\mathrm{T}_{3}$ led to approximately the same proportional increase in ME levels, averaging 11-fold over the base line (Table II). This was similar to the degree of steady-state induction, which we had previously reported as a consequence of $T_{3}$ administration with the nuclear sites fully saturated and the animals maintained on a regular chow diet (15). We have designated this an "amplified" response. Under physiological conditions the nuclear sites are onehalf occupied. Thus, the rate of response would simply double if the relationship between nuclear occupancy and response were linear. We have also shown that when animals are maintained on a high carbohydrate diet, the response to $T_{3}$ changes from a highly amplified to a nearly linear response (2). The present results confirm this finding and indicate that on the average there is only a 2.2 -fold increase when animals at every age group are maintained on a high carbohydrate diet (Table II).

In agreement with recent studies from this laboratory (4), the level of mRNA for ME in 1-mo-old rats was markedly increased after $4 \mathrm{~d}$ of the high carbohydrate diet. In contrast, little change could be detected in 1-yr-old rats. In both age groups, base-line levels of mRNA in uninduced animals were undetectable. Thus, the diminished response in ME to carbohydrate administration in the older rats appears to be reflected at the pretranslational level. These observations are clearly limited to the liver since brain ME levels neither fall with age nor do they respond to $T_{3}$ administration $(200 \mu \mathrm{g}$ for $4 \mathrm{~d})$ or a high carbohydrate diet for $4 \mathrm{~d}$ either at 1 or 12 mo (data not shown).

Relationship of hepatic ME level to food intake. The diminished basal level of ME in the aging rat and the decrease in responsivity to carbohydrate could be a reflection of decreased food intake, intrinsic diminution in responsivity of the liver, or both. In an attempt to resolve this issue measurements were made of the daily food intake in the 1-, 12-, and 18-mo-old animals studied in the experiments in Table II. Results of these measurements have been incorporated into Table III. It 
TABLE III

Total Hepatic ME Content and Food Consumption

\begin{tabular}{|c|c|c|c|c|c|}
\hline \multirow[b]{2}{*}{ Status } & \multirow[b]{2}{*}{ Age } & \multicolumn{2}{|c|}{ Daily food consumptio } & \multirow[b]{2}{*}{ Liver } & \multirow[b]{2}{*}{ Total ME } \\
\hline & & Per $100 \mathrm{~g}$ & Total & & \\
\hline & & & & $g$ & Units/liver $\times 10^{-3}$ \\
\hline \multirow[t]{5}{*}{ Euthyroid chow } & 1.0 & 17.2 & 15.6 & $4.9 \pm 0.8$ & $11.8 \pm 3.5$ \\
\hline & 1.5 & 12.9 & 21.8 & $6.6 \pm 0.5$ & $11.5 \pm 1.6$ \\
\hline & 6.0 & 9.5 & 30.8 & $13.8 \pm 1.9$ & $10.2 \pm 2.5$ \\
\hline & 12.0 & 5.2 & 30.1 & $16.9 \pm 2.5$ & $10.6 \pm 2.9$ \\
\hline & 18.0 & 4.7 & 28.1 & $17.1 \pm 3.7$ & $12.0 \pm 4.3$ \\
\hline \multirow[t]{5}{*}{ Hyperthyroid chow } & 1.0 & 13.8 & 12.3 & $4.3 \pm 0.6$ & $118.9 \pm 31.3$ \\
\hline & 1.5 & - & - & $4.9 \pm 0.5$ & $82.9 \pm 29.2$ \\
\hline & 6.0 & - & - & $9.8 \pm 0.6$ & $145.0 \pm 43.0$ \\
\hline & 12.0 & 3.9 & 23.1 & $13.5 \pm 4.1$ & $142.0 \pm 16.9$ \\
\hline & 18.0 & 3.8 & 21.6 & $12.2 \pm 2.0$ & $120.9 \pm 26.3$ \\
\hline \multirow[t]{5}{*}{ Euthyroid $\mathrm{Hi} \mathrm{CHO}$} & 1.0 & 16.2 & 13.1 & $5.8 \pm 0.9$ & $117.7 \pm 31.7$ \\
\hline & 1.5 & - & - & $6.7 \pm 1.0$ & $96.7 \pm 31.1$ \\
\hline & 6.0 & - & - & $14.8 \pm 2.0$ & $101.4 \pm 27.9$ \\
\hline & 12.0 & 4.5 & 25.1 & $15.6 \pm 2.5$ & $35.9 \pm 27.0$ \\
\hline & 18.0 & 2.5 & 14.5 & $14.2 \pm 2.3$ & $45.6 \pm 21.7$ \\
\hline \multirow[t]{5}{*}{ Hyperthyroid $\mathrm{Hi} \mathrm{CHO}$} & 1.0 & 17.8 & 15.4 & $4.2 \pm 0.5$ & $180.6 \pm 32.1$ \\
\hline & 1.5 & - & - & $5.1 \pm 0.7$ & $171.3 \pm 46.9$ \\
\hline & 6.0 & - & - & $9.3 \pm 0.5$ & $175.4 \pm 16.8$ \\
\hline & 12.0 & 2.5 & 14.5 & $12.3 \pm 0.9$ & $159.3 \pm 45.7$ \\
\hline & 18.0 & 2.5 & 16.0 & $12.1 \pm 1.2$ & $143.6 \pm 51.8$ \\
\hline
\end{tabular}

Food consumption and total hepatic ME content in animals used in the experiment summarized in Table II. Hi CHO, high carbohydrate diet.

is apparent that there was a major decrease in food consumption per $100 \mathrm{~g}$ body wt in the older animals. The weight of food consumed by 12- and 18-mo old animals was approximately one-quarter of that consumed by 1-mo-old animals. Curiously, the daily food intake per $100 \mathrm{~g}$ body wt did not increase in the hyperthyroid compared to the euthyroid groups.

Another unanticipated finding illustrated in Table III was that despite the age-related fall in ME per milligram DNA the total hepatic content of ME was remarkably constant. It therefore appeared possible to relate at least in part, the diminished hepatic ME pool per $100 \mathrm{~g}$ body wt to a diminished food intake. Nevertheless, the calculations summarized in Table IV show that the livers of the older animals also exhibit a diminished accumulation of total ME per gram of food consumed. These findings suggest that both diminished food intake per $100 \mathrm{~g}$ body wt and a decrease in hepatocellular responsivity are responsible for the decline in ME levels per milligram DNA.

\section{DISCUSSION}

The present findings confirm previous results from our laboratory that show that the basal level of hepatic ME and the response of this enzyme to $T_{3}$ administration decline with age. In our previous report (1) the oldest animal studied was 6 mo of age, whereas the range in the present series of studies was extended to 12 and 18 mo. Nevertheless, our current study showed that 12- and 18-mo-old animals exhibit only a modest further decline in basal enzyme level and response to $\mathrm{T}_{3}$ administration. Also in confirmation of

TABLE IV

Calculated Hepatic Responsivity to Dietary Induction

\begin{tabular}{llcllr}
\hline & \multicolumn{2}{c}{ Regular chow } & & \multicolumn{2}{c}{ Hi CHO diet } \\
\cline { 2 - 3 } \cline { 5 - 5 } Age & Expt. 1 & Expt. 2 & & Expt. 1 & Expt. 2 \\
\hline$m o$ & & & & \\
1 & $757(100)$ & $774(100)$ & & $8,080(100)$ & $5,267(100)$ \\
1.5 & $529(50)$ & & & \\
6 & $330(44)$ & & & $1,005(12)$ & \\
12 & $353(47)$ & & & $835(10)$ \\
18 & $427(56)$ & $301(39)$ & & $2,313(29)$ & $1,235(23)$ \\
27 & & $310(40)$ & & \\
\hline
\end{tabular}

Responsivity is defined for regular diet as total hepatic enzyme mass per gram of chow consumed; for high carbohydrate $(\mathrm{CHO})$ diet, as the increase in $\mathrm{ME}$ hepatic content per gram CHO diet consumed. Numbers in parentheses represent percentage of values at $1 \mathrm{mo}$. Primary data for experiment 1 in Table II; primary data for experiment 2 are not shown. Hi CHO, high carbohydrate; fat-free diet. 
our previous results was a failure to detect significant changes in nuclear $T_{3}$ content as determined from the product of the isotopic nuclear:plasma $\left[{ }^{125} \mathrm{I}\right] \mathrm{T}_{3}$ ratio and the concentration of circulating plasma $\mathrm{T}_{3}$. Moreover, no significant age-related changes were observed in the nuclear binding capacity as measured by in vitro saturation techniques, nor were there significant changes in $T_{3}$ metabolism with aging. As a consequence, it is apparent that age-related changes both in basal enzyme level and that induced by $T_{3}$ cannot be related to alterations in receptor content or affinity or to the metabolism of $T_{3}$, thus justifying our previous conclusion that thyroid hormone expression in the aging rat is a reflection of postreceptor modifications. Our use of a new RIA procedure has also permitted us to quantitate relatively low levels of $\mathrm{ME}$ and has allowed us to confirm our previous conclusions that age-related differences in $\mathrm{ME}$ activity are due to alterations in enzyme mass and not to changes in enzyme activity.

Perhaps the most important results from the present series of studies was the striking correlation between the age-related decline in basal $\mathrm{ME}$ levels and the diminution in $\mathrm{ME}$ response both to $\mathrm{T}_{3}$ and to carbohydrate administration. Previous studies from a number of laboratories have indicated that $\mathrm{ME}$, together with other lipogenic enzymes, is induced by a high carbohydrate low-fat diet $(16,17)$. More recent experiments from our laboratory have established that there is a synergistic relationship between $T_{3}$ and carbohydrates in the induction of $\mathrm{ME}$ and other lipogenic enzymes (2). We postulated a multiplicative process between the signal created by the $T_{3}$ nuclear interaction and that arising from the high carbohydrate diet. As a consequence, thyroidectomy results in a sharp curtailment in the generation of $\mathrm{ME}$ by carbohydrate. Conversely, in starvation the response of $\mathrm{ME}$ to $\mathrm{T}_{3}$ is markedly inhibited (18). The structural basis for this interaction is unknown and the nature of the signal that is elicted by the high carbohydrate diet has not been defined. Since fructose can interact with $T_{3}$ in animals rendered diabetic with streptozotocin to induce $\mathrm{ME}$, the carbohydrate-derived signal does not appear to be insulin itself (19). Insulin, however, may play a permissive role in allowing normal intracellular metabolism of glucose, a process that is bypassed by fructose in the diabetic liver. Recent studies with isolated hepatocytes by Mariash et al. in our laboratory (20) have shown that glucose by itself is effective in the induction of $\mathrm{ME}$ enzyme in primary hepatocyte cultures. Thus, the carbohydrategenerated signal is either a glycolytic intermediate or a product of intracellular glucose metabolism. Other studies from our laboratory have shown that the induction of $\mathrm{ME}$ both by $\mathrm{T}_{3}$ and carbohydrate can be attributed exclusively to increased formation of the specific mRNA coding for ME (4). Therefore, the high carbohydrate and $T_{3}$ nuclear signals appear to interact at a nuclear level.

In the context of these considerations we were interested to find an age-related decrease in hepatic response to a high carbohydrate diet that appeared to parallel both the decrease in the basal enzyme contents per milligram DNA and the response to $T_{3}$ administration. All three parameters exhibited the largest percentage fall between 1 and 6 mo. Despite the agerelated decrease in the mass of $\mathrm{ME}$ induced by $\mathrm{T}_{3}$, the relative or "fold-increase" in all age groups remained relatively constant (Table II). This is precisely what one would anticipate if as previously postulated $T_{3}$ serves to "multiply" the carbohydrate-induced signal.

In animals maintained on a high carbohydrate diet, $\mathrm{T}_{3}$ administration resulted in a much smaller (two to three)-fold increase. This again is in agreement with our previous results, which showed a much lesser degree of amplification by $\mathrm{T}_{3}$ maintained on a high carbohydrate diet (2). We have speculated that the high degree of amplification observed on the Chow diet is due to the stimulation of carbohydrate metabolism by $\mathrm{T}_{3}$ leading to an augmented rate of generation of the putative carbohydrate-related factor. We should now like to propose that the combined administration of $T_{3}$ and a high carbohydrate, fat-free diet results in the generation of a large abundance of the proposed intermediate or product directly responsible for $\mathrm{ME}$ induction, far in excess of what is required to drive the induction process at maximal rates. Our working hypothesis, illustrated in Fig. 5, would serve to explain the finding (Table III) that the combined administration of $\mathrm{T}_{3}$ and diet increases the total hepatic $\mathrm{ME}$ mass to nearly the same level in all age groups studied. Under any circumstance, the current data strongly support our previous proposal that $T_{3}$ acts as a multiplier of the carbohydrate dietary factor.

The concept that the hepatic $M E$ response to $T_{3}$ is linked to carbohydrate metabolism is strengthened by the observation that the level of brain ME enzyme does not fall with age and fails to respond either to $T_{3}$ or to carbohydrate administration. Although our data do not exclude the possibility that $\mathrm{ME}$ in brain and liver are distinctive isoenzymes, the hepatic and brain enzymes were not distinguishable immunologically with the antiserum used in the present studies.

The mechanism leading to the demonstrated agerelated reduction in $\mathrm{ME}$ content per milligram hepatic DNA appears to have two components, a reduction in daily food intake per $100 \mathrm{~g}$ body wt and per total liver mass, and a decrease in hepatocellular responsivity to the administration of carbohydrate. The age-related decrease in hepatic responsivity to carbohydrate administration is apparent from the ratio of the induced hepatic ME mass and the daily weight of food consumed. The reduced hepatic responsivity may well be due to an impaired intracellular metabolism of glucose. 


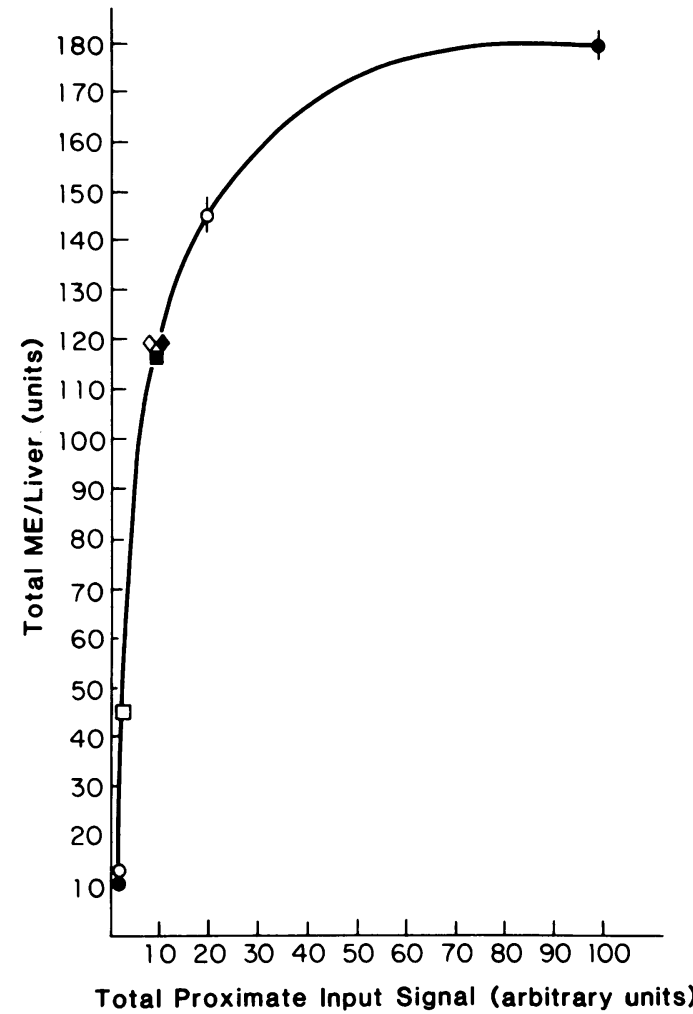

Figure 5 Hypothetical model to explain age-related changes in $M E$ response to a high carbohydrate diet and to $T_{3}$ administration. We assume that the $\mathrm{ME}$ response is governed by an input signal determined both by the amount of carbohydrate delivered to the liver and the thyroidal status of the animal. The input signal is expressed in arbitrary units, and the $\mathrm{ME}$ response system is postulated to be saturable. The postulated relationship between steady-state response and the input is represented by the function indicated. The input signal for liver ME on a regular diet for young $(\bullet)$ and old animals $(O)$ is assigned arbitrarily a value of 1 , since the total $\mathrm{ME}$ per liver in $1 \mathrm{mo}$ and $18 \mathrm{mo}$ animals is approximately the same (Table III). Administration of carbohydrates to the young animals (ם) results in an $\sim 10$-fold increase, yielding a postulated signal strength of 10 , whereas the input response of the older animal ( $\square$ ) is postulated to lead to a signal strength of only 2. (Responsivity of old animals to carbohydrate is $\sim 20 \%$, Table IV.) $\mathrm{T}_{3}$ is postulated to cause a 10 -fold increase in signal strength (Table II) yielding a value of 10 for young $(\diamond)$ and old $(\diamond)$ animals. Administration of $T_{3}$ plus the high carbohydrate diet to old animals $(\phi)$ yields an input value of $20(=2 \times 10)$ and combined stimuli in young animals $(\phi)$ a value of $100(=10 \times 10)$.

Further studies are required to establish whether there is any relationship between this phenomenon and the documented impairment of glucose tolerance in the aging rat (21). The impaired response in the level of specific mRNA sequences coding for ME in the carbohydrate-stimulated aging rat indicates that the basis of the defect resides at the pretranslational level.

Lastly, previous experiments have also shown that the level of the mitochondrial enzyme $\alpha$-glycerophos- phate dehydrogenase falls with age as does its response to $T_{3}$ (1). Unfortunately, little is known about the biological function of this enzyme. Nevertheless, by analogy with the present results it is at least theoretically conceivable that factors as yet unidentified are primarily responsible for inducing $\alpha$-glycerophosphate dehydrogenase and that such inducers decline with age. One could thus hypothesize that $\mathrm{T}_{3}$ serves to multiply such a signal. Several examples of a coordinate interrelationship between $T_{3}$ and other hormones have recently drawn considerable attention. Thus, the induction of the exportable hepatic protein $\alpha_{2 u}$-globulin in the rat requires not only $\mathrm{T}_{3}$ but dihydrotestosterone and cortisol (22). There also appears to be a synergistic interaction between cortisol and $\mathrm{T}_{3}$ in the induction of mRNA for growth hormone in rat pituitary tumor cells $(23,24)$. These examples prompted the speculation that $T_{3}$ may function in general by amplifying primary signals involved in genetic regulation. Recent studies have shown that receptors for $\mathrm{T}_{3}$ are bound to a $5.8 \mathrm{~S}$ linker fragment in a portion of chromatin that is highly accessible to nuclease digestion and thus presumably to endogenous polymerase II action (25). There also appear to be no gross differences in the susceptibility of chromatin from hypothyroid animals to nuclease digestion. These findings support the concept that $\mathrm{T}_{3}$ does not primarily increase the accessibility of genes but in some undefined fashion $T_{3}$ in concert with other hormones and factors accelerates the rate of transcription or processing of specific mRNA sequences.

\section{ACKNOWLEDGMENTS}

We should like to acknowledge the expert technical support of Mr. Robert Gunville, Ms. Ana Martinez, and Ms. Carolyn McSwigan, as well as the editorial-secretarial support of Ms. Nancy Rutledge and Ms. Colleen Jahnel.

This work was supported by National Institutes of Health grants AM019812 and AM26919, Special Service Research Awards AM05880 and AG05125, Clinical Investigator Award AM00800, and Training Grant AM07203.

\section{REFERENCES}

1. Schwartz, H. L., M. A. Forciea, C. N. Mariash, and J. H. Oppenheimer. 1979. Age-related reduction in response of hepatic enzymes to 3,5,3'-triiodothyronine administration. Endocrinology. 105: 41-46.

2. Mariash, C. N., F. E. Kaiser, H. L. Schwartz, H. C. Towle, and J. H. Oppenheimer. 1980. Synergism of thyroid hormone and high carbohydrate diet in the induction of lipogenic enzymes in the rat. J. Clin. Invest. 65: $1126-1134$

3. Wooley, J. G., and W. H. Sebrell. 1945. Niacin (nicotinic acid) an essential growth factors for rabbits fed a purified diet. J. Nutr. 29: 191-199.

4. Towle, H. C., C. N. Mariash, and J. H. Oppenheimer. 1980. Changes in the hepatic levels of messenger ribonucleic acid for malic enzyme during induction by thyroid hormone or diet. Biochemistry. 19: 579-585.

5. Bolton, A. E., and W. M. Hunter. 1973. The labeling of proteins to high specific radioactivities by conjugation 
to an I-containing alkylating agent. Biochem. J. 133: 529-539.

6. Rodbard, D. 1974. Apparent positive cooperative effects in cyclic AMP and corticosterone production by isolated adrenal cells in response to ACTH analogues. Endocrinology. 94: 1427-1437.

7. Hsu, R. Y., and H. A. Lardy. 1969. Malic enzyme. Methods Enzymol. 13: 230-235.

8. Schuster, L. D., H. L. Schwartz, and J. H. Oppenheimer. 1979. Nuclear receptors for 3,5,3'-triiodothyronine in human liver and kidney. Characterization, quantitation and similarities to rat receptors. J. Clin. Endocrinol. Metab. 48: 627-632.

9. Oppenheimer, J. H., H. L. Schwartz, and M. I. Surks. 1974. Tissue differences in the concentration of triiodothyronine nuclear binding sites in the rat; liver, kidney, pituitary, heart, brain, spleen and testis. Endocrinology. 95: 897-903.

10. Surks, M. I., A. R. Schadlow, and J. H. Oppenheimer. 1972. A new radioimmunoassay for plasma L-triiodothyronine. Measurements in thyroid disease and in patients maintained on hormonal replacement. J. Clin. Invest. 51: 3104-3113.

11. Oppenheimer, J. H., H. L. Schwartz, H. C. Shapiro, G. Bernstein, and M. I. Surks. 1970. Differences in primary cellular factors influencing the metabolism and distribution of 3,5,3'-L-triiodothyronine and L-thyroxine. $J$. Clin. Invest. 49: 1016-1024.

12. Giles, K. W., and A. Meyers. 1965. An improved diphenylamine method for estimation of deoxyribonucleic acid. Nature (Lond.). 206: 93.

13. Munro, H. N., and A. Fleck. 1966. The determination of nucleic acids. Methods Biochem. Anal. 14: 113-176.

14. Lowry, O. H., N. J. Rosebrough, A. L. Farr, and R. J. Randall. 1951. Protein measurement with the Folin phenol reagent. J. Biol. Chem. 193: 265-275.

15. Oppenheimer, J. H., P. Coulombe, H. L. Schwartz, and N. W. Gutfeld. 1978. Nonlinear (amplified) relationship between nuclear occupancy by triidothyronine and the appearance rate of hepatic $\alpha$-glycerophosphate dehydrogenase and malic enzyme in the rat. J. Clin. Invest. 61: 987-997.

16. Tepperman, H. M., and J. Tepperman. 1964. Patterns of dietary and hormonal induction of certain NADP-linked liver enzymes. Am. J. Physiol. 206: 357-361.

17. Tarentino, A. L., D. A. Richert, and W. W. Westerfield. 1966. The concurrent induction of hepatic $\alpha$-glycerophosphate dehydrogenase and malate dehydrogenase by thyroid hormone. Biochem. Biophys. Acta. 124: 295-309.

18. Dillmann, W. H., H. L. Schwartz, and J. H. Oppenheimer. 1978. Selective alterations in hepatic enzyme response after reduction of nuclear triiodothyronine receptor sites by partial hepatectomy and starvation. Biochem. Biophys. Res. Commun. 80: 259-266.

19. Kaiser, F. E., C. N. Mariash, H. L. Schwartz, and J. H. Oppenheimer. 1980. Inhibition of malic enzyme induction by triiodothyronine in the diabetic rat: reversal by fructose feeding. Metab. Clin. Exp. 29: 767-772.

20. Mariash, C. N., C. McSwigan, H. L. Schwartz, and J. H. Oppenheimer. 1981. Clin. Res. 29: 414A (Abstr.).

21. Bracho-Romero, E., and G. M. Reaven. 1977. Effect of age and weight on plasma glucose and insulin responses in the rat. J. Am. Geriatr. Soc. 25: 299-302.

22. Roy, A. K., and D. J. Dowbenko. 1977. Role of growth hormone in the multi-hormonal regulation of messenger RNA for alpha $\mathrm{a}_{2 \mathrm{U}}$-globulin in the liver of hypophysectomized rats. Biochemistry. 16: 3918-3922.

23. Samuels, H. H., Z. D. Horwitz, F. Stanley, J. Casanova, and L. E. Shapiro. Thyroid hormone controls glucocorticoid action in cultured GH cells. Nature (Lond.). 268: $254-257$.

24. Martial, J. A., J. D. Baxter, H. M. Goodman, and P. H. Seeburg. 1977. Regulation of growth hormone messenger RNA by thyroid and glucocorticoid hormones. Proc. Natl. Acad. Sci. U. S. A. 74: 1816-1820.

25. Jump, D. B., and J. H. Oppenheimer. 1980. Thyroid hormone receptor-containing fragment release from chromatin by deoxyribonuclease I and micrococcal nuclease. Science (Wash. D. C.). 209: 811-813. 